\title{
nature
}

\section{Opportunity in Kyoto for a president's legacy}

The success or failure of global climate negotiations rests on the shoulders of Bill Clinton, who can enhance his stature by holding his nerve in the face of industry's scare-mongering.

A fter more than ten years of heated scientific and political argument about the threat of anthropogenic climate change, the decisive moment approaches. December's conference of nations in Kyoto will either commit the planet to a sensible response, or visibly fail to do so. If there is one person who can singlehandedly have a major impact on the outcome, it is the president of the United States.

This week in Washington, President Bill Clinton gathered together an impressive array of scientific and political talent to discuss publicly the global warming issue. The event was the culmination of a serious, if somewhat belated, attempt by the president to offer leadership to the American people on this issue.

Although the signals coming from Clinton's advisers are mixed and inconclusive, the president's own recent statements suggest that he is determined that there should be a meaningful agreement at Kyoto. Last week, in an imaginative public relations initiative, he invited television weathercasters (many of whom conceal advanced meteorological degrees underneath their cheerful countenances) from all over the United States to the White House for an education session on global warming. "I want to try to get America to accept the fact that the majority scientific opinion, the overwhelming majority scientific opinion, is accurate," he told them.

What is required now is for the administration to muster the political courage it regrettably needs, to commit itself to firm targets and timetables for emission reductions that it would like to achieve, and to go to Kyoto in good faith to negotiate a deal. But that is easier said than done. The United States was due to publish its targets in June: so far it has failed to do so, causing much exasperation elsewhere. But inside the United States, that failure is seen as a sensible precaution against a lengthy onslaught from the industrial interests that oppose any meaningful agreement.

The debate in each developed country has been substantially similar to that in the United States. American aversion to taxation - and energy taxation in particular — has clearly played a role in that country's laggardly approach to climate change. But Americans are not alone in disliking taxes. US public awareness of environmental issues in general is high. But the lack of a firm political culture allows industrial and labour interests the opportunity to buy influence in the debate. From the outset, those interests have sought to nurture a group of scientific nay-sayers, many from outside the field of climate science. This group has distorted the scientific debate, perpetuating a misleading argument about the absence of proof of an anthropogenic component to climate change at a time when the principal argument in the scientific literature was about the scale of that component.

That strategy now appears to be coming apart. Opinion polls suggest that it has had little impact on US public opinion (see page 531). More tellingly, industry has switched the focus of its attack: in its latest, \$15-million television advertising campaign, xenophobia has replaced junk science as the central argument for inaction. The decision of Ted Turner's CNN network to stop running the advertisements is an imperious declaration of good taste.
The effectiveness of industry's direct overtures to the public will fortunately be limited by its past record of crying wolf on the threats posed by previous environmental measures. The same groups vigorously and unsuccessfully opposed clean air, clean water, catalytic converters and restrictions on sulphur dioxide emissions and CFCs, to name but a few. But these industrial and labour interests are, one way and another, able to exert strong influence on the 100 senators who must ratify any agreement to come out of Kyoto. The Senate has already exercised its constitutional right to advise the president on the negotiations by means of a non-binding resolution, sponsored by Robert Byrd (Democrat, West Virginia), which it passed unanimously in August. The Byrd resolution contains potential obstacles to agreement in Kyoto, but these are not insurmountable. It asks that any agreement "mandates new specific scheduled commitments to limit or reduce greenhouse gas emissions for developing country parties within the same compliance period" as the agreement between developed countries.

\section{Proposals}

US officials do not expect developing countries to join in any agreement reached by developed countries at Kyoto: they hope to persuade them to accept an appendix to the agreement, which might, for example, set out a binding timetable for negotiations that will bring the developing countries into the process at a later date. Treaty opponents want Clinton to push this point hard, perhaps hoping to prompt a breakdown in the talks: they will surely be disappointed.

The other issue that America will bring to Kyoto is a proposal for the trading of pollution permits between governments, to ease compliance. That would allow rich countries to buy their way out of trouble through bilateral agreements with poorer countries. After some early suspicion, other countries are coming round to the idea, provided that the permits are for deliberate future cuts in emissions, and not for past accidental events, such as the slump in emissions from Eastern Europe and Russia in the early 1990s and recent declines in UK emissions following privatization of energy suppliers.

Evidence of good faith from the developing countries, together with acceptance of permit trading, could open the way for an historic agreement at Kyoto. Such an agreement may require the United States to go further than the stabilization proposal that the Clinton administraton is now considering. Japan's target of an average 5 per cent cut below 1990 levels by 2010 is the minimum that developing countries should demand as evidence of the developed world's own good intentions. Europe's role will be as a broker between the United States and the developing countries. Australia, which is opposing strict limitations, can expect to find itself thoroughly isolated.

Bringing back such an agreement and selling it will require considerable courage from a Democrat administration that can expect to be attacked where it hurts - on the tax issue. At last, Clinton seems to be warming to a task befitting a flawed but popular president in search of a legacy. Success at Kyoto requires no less. 